\title{
A HYBRID MCDM APPROACH TO ASSESS THE SUSTAINABILITY OF STUDENTS' PREFERENCES FOR UNIVERSITY SELECTION
}

\author{
Mehmet KABAK ${ }^{\mathrm{a}}$, Metin DAĞDEVIREN ${ }^{\mathrm{b}}$ \\ ${ }^{a}$ Department of Industrial and System Engineering, Turkish Military Academy, \\ Bakanliklar, 06654 Ankara, Turkey \\ ${ }^{\mathrm{b}}$ Department of Industrial Engineering, Gazi University, \\ Maltepe, 06570 Ankara, Turkey
}

Received 03 December 2011; accepted 17 November 2012

\begin{abstract}
Selection of the most suitable university among many alternatives is a multi-criteria decision making (MCDM) problem. In this paper, an integrated approach which employs analytic network process (ANP) and preference ranking organization method for enrichment evaluations (PROMETHEE) together, is proposed for this problem. By the way, the paper is concerned with criteria influencing student choice in Turkey to establish if there is any need in developing a multi-criteria model for predicting students' preference for universities. The ANP is used to analyse the structure of the university selection problem and to determine weights of the criteria, and the PROMETHEE method is used to obtain final ranking, and to make a sensitivity analysis by changing the weights for criteria. The results indicate that three factors, future career prospects and opportunities, scholarship and university's social life at the top in the university selection.
\end{abstract}

Keywords: multi criteria decision making, ANP, PROMETHEE, sensitivity analysis, university selection.

JEL Classification: C02, C44, C52, C54, D81, H52.

\section{Introduction}

The decision to go to college may be one of the most important decisions a young person will ever make. Why college selection is very important? A college education is not only one of the most expensive purchases that many people will ever make, but also one that has lifelong ramifications in terms of occupation, income and lifestyle (Conard, M. J., Conard, M. A. 2000). Deciding to attend college is often monumental to a young person.

Corresponding author Mehmet Kabak

E-mail:mkabak@kho.edu.tr 
It is compounded by the fact that a defined time frame mandates the process and that the outcomes can be potentially significant. Additional life-changing considerations include the possibility of moving to a new location, developing new relationships, accruing debt, and deciding on a course of action that might significantly affect future life and career plans (Pampaloni 2010).

It appears that gaining information about multiple aspects about colleges is an integral part of their decision-making process. Attempting to fulfil the need for knowledge about such a broad range of concerns could complicate an already stressful decision-making period for the student. From a student's perspective, it is crucial that adequate information is available so that a well-informed decision can be made (Briggs 2006; Briggs, Wilson 2007; Simões, Soares 2010). In this framework, a number of studies have examined the influence of a large number of factors on the decision to choose university including academic, non-academic, psychological and sociological characteristics like quality of faculty, reputation of university, cost, social life, family and peers, etc. (Broekemier, Seshadri 2000; Poock, Love 2001; Soutar, Turner 2002; Holdsworth, Nind 2006; Vrontis et al. 2007; Adams, Evenland 2007; Anctil 2008; Bergerson 2009; Gordona, Berhow 2009; Lei, Chuang 2010).

If universities/colleges can predict what factors influence their applicants' decision, they can have advantage at the competition to get best students to their institutions while scarce resources can be focused on right areas and applicants could be satisfied and happy within their life (Cremonini et al. 2008; Taylor et al. 2008; Sojkin et al. 2011).

Higher education can result in economic growth through personal and public channels. The personal benefits are well established and better employment prospects, higher salaries (Bloom et al. 2005). Preferred and suitable education and also correct employment as a result enable individuals to work more productively over a longer time, further boosting lifetime earnings. In addition, quality of university researchers and employees that requires willingness and ability correlation with employment for which we propose a MCDM model in this study can assist with the refinement of existing technologies and the development of new techniques in industry.

In general, researches in literature on university selection consider admissions rather than applications and use statistical techniques.

A number of studies have examined the influence of college choice criteria of high school students and their parents and, in addition, tested for differences in importance ratings between male and female students. They also investigated how influential parents are in the choice process from both the deciding students' and their parents' perspectives. According to the conclusion, to students, institutions should emphasize available programs of study, cost advantages, availability of financial aid/scholarships, job placement after graduation, and facility quality. In addition, greater emphasis should be placed on academic reputation and safety when attempting to attract female students. To parents, available programs of study, safety, cost advantages, academic reputation, and facility quality are the most important criteria (Broekemier, Seshadri 2000; Poock, Love 2001; Veloutsou et al. 2004; Warwick, Mansfield 2004; Holdsworth, Nind 2006; Briggs, Wilson 2007; Vrontis et al. 2007; Cremonini et al. 2008). 
Some of the researches have concentrated on their own national higher educational systems and countries like Scotland, Poland, Norway, and Greece. Briggs (2006) explored the factors influencing student choice in two undergraduate disciplines, accountancy and engineering, across the six universities in Scotland and developed model for predicting institutional choice for Scottish undergraduate entry. After analysis, the top three factors were academic reputation, distance from home and location, respectively.

Støren and Arnesen (2007) examined sex segregation in higher education in Norway. They analysed parent's education and occupation and students' grades have an impact on the choice of male and female dominated subjects. The main issue addressed was the degree to which parent's occupation and education, and students' grades in upper secondary education affect choices of male-dominated, female-dominated or gender-neutral higher education. According to the results, among women, mother's higher education had a positive effect on male-dominated educational choices, while father's higher education has a positive effect on gender-neutral educational choices, both resulting in a reduced probability of choosing a female (conventional) education.

Menon et al. (2007) attempted to determine the nature of the decision making process which precedes the choice of a higher education institution in Greece, especially in relation to the degree of rationality exhibited by potential students. Specifically, they investigated the extent to which prospective students engage in information search prior to the choice of an institution. Information search is used as an operative measure of rationality based on the hypothesis that high information seekers will exhibit a greater degree of rationality in their decision-making than low information seekers.

The other relevant criteria for the selection of a university, which might change a little according to the country and culture, have been searched in the literature, compiled and presented in Table 1. These criteria form the basis of our study for the development of an Analytic Network Process (ANP)-Preference Ranking Organization METHod for Enrichment Evaluations (PROMETHEE) model to choice a university.

Table 1. Summary of literature on the criteria for the selection of a university

\begin{tabular}{|c|c|c|}
\hline $\begin{array}{l}\text { Selection } \\
\text { criteria }\end{array}$ & Relevance in university & References \\
\hline \multicolumn{3}{|l|}{ Academic } \\
\hline $\begin{array}{l}\text { Quality of } \\
\text { faculty }\end{array}$ & $\begin{array}{l}\text { Reference to faculty, teachers, } \\
\text { professors. }\end{array}$ & $\begin{array}{l}\text { M. J. Conard and M. A. Conard (2000), Soutar and } \\
\text { Turner (2002), Warwick and Mansfield (2004), } \\
\text { Briggs (2006), Briggs and Wilson (2007), Simões } \\
\text { and Soares (2010), Pampaloni (2010), } \\
\text { Lei and Chuang (2010). }\end{array}$ \\
\hline $\begin{array}{l}\text { Quality of } \\
\text { program }\end{array}$ & $\begin{array}{l}\text { References to academic programs, } \\
\text { majors/minors, available courses } \\
\text { and specific program choices; also } \\
\text { includes more general references } \\
\text { to academics and/or the type of } \\
\text { education (but not faculty). }\end{array}$ & $\begin{array}{l}\text { M. J. Conard and M. A. Conard (2000), } \\
\text { Broekemier and Seshadri (2000), Soutar and } \\
\text { Turner (2002), Warwick and Mansfield (2004), } \\
\text { Briggs (2006), Vrontis et al. (2007), Simões and } \\
\text { Soares (2010), Pampaloni (2010). }\end{array}$ \\
\hline
\end{tabular}


Continued Table 1

\begin{tabular}{|c|c|c|}
\hline $\begin{array}{l}\text { Selection } \\
\text { criteria }\end{array}$ & Relevance in university & References \\
\hline $\begin{array}{l}\text { Reputation of } \\
\text { university }\end{array}$ & $\begin{array}{l}\text { It focuses on earlier } \\
\text { performance of the university } \\
\text { not current situation. } \\
\text { Reference to school's status, } \\
\text { prestige, quality (specific } \\
\text { to schools, NOT programs), } \\
\text { credentials, ranking. }\end{array}$ & $\begin{array}{l}\text { Broekemier and Seshadri (2000), M. J. Conard } \\
\text { and M. A. Conard (2000), Poock and Love (2001), } \\
\text { Soutar and Turner (2002), Veloutsou et al. (2004), } \\
\text { Warwick and Mansfield (2004), Briggs (2006), } \\
\text { Briggs and Wilson (2007), Lei and Chuang (2010), } \\
\text { Simões and Soares (2010), Pampaloni (2010). }\end{array}$ \\
\hline $\begin{array}{l}\text { Courses } \\
\text { studied }\end{array}$ & $\begin{array}{l}\text { The content of specific courses } \\
\text { and the course as a learning } \\
\text { experience. }\end{array}$ & $\begin{array}{l}\text { Veloutsou et al. (2004), } \\
\text { Warwick and Mansfield (2004), } \\
\text { Briggs and Wilson (2007). }\end{array}$ \\
\hline \multicolumn{3}{|l|}{ Non-academic } \\
\hline $\begin{array}{l}\text { Geographic } \\
\text { location of } \\
\text { university }\end{array}$ & $\begin{array}{l}\text { Includes references to } \\
\text { distance from student's home, } \\
\text { proximity to or identification } \\
\text { of other points (cities, attractions), } \\
\text { setting (rural/urban) and } \\
\text { weather. }\end{array}$ & $\begin{array}{l}\text { Broekemier and Seshadri (2000), Poock and Love } \\
\text { (2001), Veloutsou et al. (2004), Warwick and } \\
\text { Mansfield (2004), Holdsworth and Nind (2006), } \\
\text { Briggs (2006), Vrontis et al. (2007), Briggs and } \\
\text { Wilson (2007), Lei and Chuang (2010), Simões and } \\
\text { Soares (2010), Pampaloni (2010). }\end{array}$ \\
\hline $\begin{array}{l}\text { Institution's } \\
\text { infrastructure }\end{array}$ & $\begin{array}{l}\text { It is related to library facilities, } \\
\text { size of class, number of } \\
\text { students per class, computer } \\
\text { labs, health facilities, } \\
\text { counselling services and } \\
\text { accommodation. }\end{array}$ & $\begin{array}{l}\text { Broekemier and Seshadri (2000), } \\
\text { M. J. Conard and M. A. Conard (2000), } \\
\text { Veloutsou et al. (2004), Holdsworth and } \\
\text { Nind (2006), Lei and Chuang (2010), } \\
\text { Simões and Soares (2010), Pampaloni (2010). }\end{array}$ \\
\hline Cost & $\begin{array}{l}\text { It might be related to } \\
\text { the university fees, travel } \\
\text { expenses, tuition fees, } \\
\text { accommodation, living } \\
\text { expenses in the campus/city } \\
\text { and scholarship financed by } \\
\text { governmental or } \\
\text { non-governmental } \\
\text { organizations. }\end{array}$ & $\begin{array}{l}\text { Broekemier and Seshadri (2000), M. J. Conard and } \\
\text { M. A. Conard (2000), Poock and Love (2001), } \\
\text { Warwick and Mansfield (2004), Holdsworth and } \\
\text { Nind (2006), Briggs and Wilson (2007), } \\
\text { Vrontis et al. (2007), Cremonini et al. (2008), } \\
\text { Lei and Chuang (2010), Simões and Soares (2010), } \\
\text { Pampaloni (2010). }\end{array}$ \\
\hline $\begin{array}{l}\text { Future career } \\
\text { prospects and } \\
\text { opportunities }\end{array}$ & $\begin{array}{l}\text { Students might expect } \\
\text { monetary or non-monetary } \\
\text { benefits. Generally, main goal } \\
\text { for most of the students is } \\
\text { a well-paid job and career. } \\
\text { It is relate to opportunity to find } \\
\text { summer and part-time jobs. }\end{array}$ & $\begin{array}{l}\text { Broekemier and Seshadri (2000), M. J. Conard and } \\
\text { M. A. Conard (2000), Poock and Love (2001), } \\
\text { Soutar and Turner (2002), Veloutsou et al. (2004), } \\
\text { Briggs (2006), Holdsworth and Nind (2006), } \\
\text { Briggs and Wilson (2007), Lei and Chuang (2010), } \\
\text { Simões and Soares (2010), Pampaloni (2010). }\end{array}$ \\
\hline $\begin{array}{l}\text { Local } \\
\text { infrastructure }\end{array}$ & $\begin{array}{l}\text { It is related to safety, } \\
\text { transportation and behaviours } \\
\text { of locals to students. }\end{array}$ & $\begin{array}{l}\text { Veloutsou et al. (2004), Warwick and Mansfield } \\
\text { (2004), Lei and Chuang (2010), Pampaloni (2010). }\end{array}$ \\
\hline $\begin{array}{l}\text { Local } \\
\text { social life }\end{array}$ & Social activities nearby. & $\begin{array}{l}\text { Broekemier and Seshadri (2000), } \\
\text { Veloutsou et al. (2004), Warwick and Mansfield (2004), } \\
\text { Pampaloni (2010), Briggs (2006) Vrontis et al. (2007), } \\
\text { Briggs and Wilson (2007). }\end{array}$ \\
\hline
\end{tabular}


End of Table 1

\begin{tabular}{|c|c|c|}
\hline $\begin{array}{l}\text { Selection } \\
\text { criteria }\end{array}$ & Relevance in university & References \\
\hline $\begin{array}{l}\text { University's } \\
\text { social life }\end{array}$ & $\begin{array}{l}\text { University's organizations and } \\
\text { the city's night life, friends } \\
\text { at the same university. }\end{array}$ & $\begin{array}{l}\text { Broekemier and Seshadri (2000), } \\
\text { Veloutsou et al. (2004), Warwick and Mansfield (2004), } \\
\text { Vrontis et al. (2007), Pampaloni (2010). }\end{array}$ \\
\hline Campus & $\begin{array}{l}\text { Reference to more physical } \\
\text { campus, including appearance, } \\
\text { architecture, buildings and } \\
\text { safety in campus. }\end{array}$ & $\begin{array}{l}\text { Broekemier and Seshadri (2000), Poock and } \\
\text { Love (2001), Veloutsou et al. (2004), Warwick and } \\
\text { Mansfield (2004), Vrontis et al. (2007), Briggs and } \\
\text { Wilson (2007), Lei and Chuang (2010). }\end{array}$ \\
\hline $\begin{array}{l}\text { Surrounding } \\
\text { communities }\end{array}$ & $\begin{array}{l}\text { General public behaviours } \\
\text { and influences/media. }\end{array}$ & $\begin{array}{l}\text { Warwick and Mansfield (2004), } \\
\text { Vrontis et al. (2007), Briggs and Wilson (2007). }\end{array}$ \\
\hline $\begin{array}{l}\text { Family, peer } \\
\text { and teacher's } \\
\text { influence }\end{array}$ & $\begin{array}{l}\text { Students are influenced } \\
\text { parents' career, word-of-mouth } \\
\text { recommendations of friends } \\
\text { and teachers' advices. }\end{array}$ & $\begin{array}{l}\text { Broekemier and Seshadri (2000), } \\
\text { Vrontis et al. (2007), Briggs and Wilson (2007), } \\
\text { Christie (2007), Bergerson (2009), Pampaloni (2010), } \\
\text { Lei and Chuang (2010), Simões and Soares (2010). }\end{array}$ \\
\hline $\begin{array}{l}\text { Relatives living } \\
\text { in the area }\end{array}$ & $\begin{array}{l}\text { Relatives nearby could help } \\
\text { for orientation for the first } \\
\text { year especially. It also affects } \\
\text { accommodation, cost, etc. } \\
\text { indirectly. }\end{array}$ & $\begin{array}{l}\text { Poock and Love (2001), Christie (2007), } \\
\text { Lei and Chuang (2010), Pampaloni (2010). }\end{array}$ \\
\hline $\begin{array}{l}\text { Speedy } \\
\text { approval of visa }\end{array}$ & $\begin{array}{l}\text { Relate to international } \\
\text { students. }\end{array}$ & Lei and Chuang (2010). \\
\hline $\begin{array}{l}\text { Foreign } \\
\text { language } \\
\text { requirements }\end{array}$ & $\begin{array}{l}\text { Reference to teaching } \\
\text { in foreign languages. }\end{array}$ & Lei and Chuang (2010). \\
\hline Transportation & $\begin{array}{l}\text { Reference to transportation to } \\
\text { campus, city and home. }\end{array}$ & Lei and Chuang (2010). \\
\hline $\begin{array}{l}\text { Athletic } \\
\text { ranking or } \\
\text { reputation }\end{array}$ & $\begin{array}{l}\text { It includes also athletic } \\
\text { facilities. }\end{array}$ & $\begin{array}{l}\text { Broekemier and Seshadri (2000), Warwick and } \\
\text { Mansfield (2004), Holdsworth and Nind (2006), } \\
\text { Briggs and Wilson (2007), Lei and Chuang (2010), } \\
\text { Pampaloni (2010). }\end{array}$ \\
\hline $\begin{array}{l}\text { Religious } \\
\text { activities }\end{array}$ & $\begin{array}{l}\text { Religious tolerance and freedom } \\
\text { to perform religious activities } \\
\text { freely. }\end{array}$ & $\begin{array}{l}\text { Warwick and Mansfield (2004), } \\
\text { Vrontis et al. (2007), Pampaloni (2010). }\end{array}$ \\
\hline $\begin{array}{l}\text { Reputation for } \\
\text { disabled }\end{array}$ & $\begin{array}{l}\text { Reference to accommodation, } \\
\text { transportation, etc. for disabled. }\end{array}$ & Briggs and Wilson (2007). \\
\hline $\begin{array}{l}\text { Information } \\
\text { supplied by } \\
\text { universities }\end{array}$ & $\begin{array}{l}\text { Website, catalogues, } \\
\text { magazines, campus tours, etc. }\end{array}$ & $\begin{array}{l}\text { Briggs (2006), Vrontis et al. (2007), Briggs and } \\
\text { Wilson (2007), Adams and Evenland (2007), } \\
\text { Anctil (2008), Gordona and Berhow (2009), } \\
\text { Pampaloni (2010). }\end{array}$ \\
\hline
\end{tabular}

This paper presents the findings of a study on the choice of a university in Turkey and tries to show right direction to high education providers. The following aims guide the investigation reported in the study. First, attendance to higher education in Turkey is described. After explanation of ANP and PROMETHEE methods, the proposed ANP-PROMETHEE integrated model is presented and the stages of the proposed approach are determined in detail. Then, how the proposed approach is used on a real case is explained. Conclusions and future research directions are discussed in the last sections of the paper. 


\section{Higher education in Turkey}

Turkey has a different educational system from the rest of Europe. In Turkey, candidates have to pass the university entrance exam to be a university student. According to their scores, students attend public or private universities. Public university is an institution founded by state; it provides education free, to which students pay very low tuition per semesters. But, in general, the score they demand is quite high compared to the score which private universities demand.

Private universities, in other words foundation universities are founded by the private enterprise. Students also need to pass the university entrance examination to join at private universities. However, in most cases, but not in all, the score private universities require is not as high as what state universities demand and students have to pay really high tuition unless they are students with scholarship.

There is a huge difference between the demand for the higher education and the places available in Turkey as a result of the young population. Every year about one and half million students apply two central selection exams, passing to higher education exam (YGS) and university placement exam (LYS) organized by the student selection and the placement centre (ÖSYM). Approximately half of these students, about seven hundred fifty thousands, pass the exam and have a chance to go to the university, others couldn't have enough score required to go to a university. In 2010, 1.588.624 students had the YGS and LYS exams, 763.516 students could have a chance to be admitted to a university (The CoHE 2010). A student who faces a lot of challenges must know all details, factors, criteria, in other words all variables affecting the process to be able to attend the most suitable university.

\section{Method}

University selection is a problem which can be solved by statistical methods like SPSS, chisquare tests, exploratory analysis (EFA), ANOVA, logistic regression analysis or by using some tests like admissions testing (Menon et al. 2007; Simões, Soares 2010; Sojkin et al. 2011; Edwards et al. 2012). At the same time, it is a multi-criteria decision problem which can be modelled and solved by a numerous number of multi-criteria decision making methods. A lot of MCDM methods like AHP, ANP, TOPSIS, DEMATEL, ELECTRE, and PROMETHEE are used to solve vendor, equipment, location, personnel and strategy selection problems (Shyur 2006; Wu et al. 2009, 2012; Lin, Tsai 2010; Fouladgar et al. 2012). In this paper we focus on students' opinions and use ANP and PROMETHEE methods to choose the most appropriate university.

Multi-criteria decision making methods such as ANP, used for selection problems in the literature, make the evaluations using a Likert-type scale and preference functions on the criteria basis. ANP which allows for complex interrelationships among decision levels and factors is preferred to determine factors' weights. Definition of different preference functions that are 6 functions in PROMETHEE for the criteria is an important factor which affects the correctness of the decision made. Unlike other ranking methods in literature, different preference functions can be defined for criteria in PROMETHEE method (Goumas, Lygerou 2000; 
Wang, Yang 2007; Cavalcante et al. 2010). In this paper, to solve the university selection problem, the PROMETHEE method is selected due to its simplicity and capacity to approximate the way that human mind expresses and synthesizes preferences when facing multiple contradictory decision perspectives. The PROMETHEE has some strength in comparison with existing methods like AHP, ANP, TOPSIS, VIKOR, etc., such as: the PROMETHEE I does not aggregate good scores on some criteria and bad scores on other criteria, it has less pairwise comparisons and it does not have the artificial limitation of the use of the standard scale for evaluation. Decision Lab is software which supports this method and it also makes sensitivity analysis for the results. This method provides a visual and powerful tool called Geometrical Analytic for Interactive Aid (GAIA) plane to identify conflicts among criteria and to group the alternatives (Albadvi et al. 2007).

In this paper, ANP-PROMETHEE integrated approach for selection of the most suitable university will be introduced and the implementation process will be explained with a real case application. We shall use the ANP method to analyse the structure of the university selection problem and determine the weights of criteria/factors, and use PROMETHEE method for final ranking. In the application, the criteria which have the greatest effect on the university selection are determined via a sensitivity analysis.

\subsection{The ANP method}

The ANP, introduced by Saaty, is a generalization of the analytic hierarchy process (AHP) (Saaty 1996). Whereas AHP represents a framework with a uni-directional hierarchical AHP relationship, ANP allows for complex interrelationships among decision levels and attributes. The ANP feedback approach replaces hierarchies with networks in which the relationships between levels are not easily represented as higher or lower, dominant or subordinate, direct or indirect (Meade, Sarkis 1999). For instance, not only does the importance of the criteria determine the importance of the alternatives, as in a hierarchy, but also the importance of the alternatives may have impact on the importance of the criteria (Saaty 1996). Therefore, a hierarchical structure with a linear top-to-bottom form is not suitable for a complex system.

AHP is a comprehensive framework that is designed to cope with the intuitive, the rational, and the irrational when we make multi-objective, multi-criterion, and multi-actor decisions, with or without certainty for any number of alternatives. The basic assumptions of AHP are that it can be used in functional independence of an upper part or cluster of the hierarchy from all its lower parts and the criteria or items in each level (Meade, Sarkis 1999). Many decision-making problems cannot be structured hierarchically because they involve the interaction and dependence of higher level elements on lower level elements (Saaty, Takizawa 1986; Saaty 1996). Structuring a problem involving functional dependence allows for feedback among clusters. This is a network system. Saaty (1996) suggested the use of AHP to solve the problem of independence on alternatives or criteria, and the use of ANP to solve the problem of dependence among alternatives or criteria.

The major difference between AHP and ANP is that ANP is capable of handling interrelationships between the decision levels and attributes by obtaining the composite weights through the development of a "supermatrix" (Shyur 2006). The supermatrix is actually a parti- 
tioned matrix, where each matrix segment represents a relationship between two components or clusters in a system (Saaty 1996). In addition to this, final weights can be calculated using matrix operations, especially where the numbers of criteria in the model are relatively few. Matrix operations are used in order to convey with ease the workings of the methodology used and how dependencies are worked out. Supermatrix is without doubt the better choice when the number of elements increases (Yüksel, Dağdeviren 2007). Matrix operations of Saaty and Takizawa (1986) were used in this study as they are easy-to-understand in the calculation of the weights of criteria by ANP.

The process of ANP involves three sub steps shown as follows (Shyur 2006):

Step 1: Without assuming the interdependence among criteria, the decision makers are asked to evaluate all proposed criteria pairwise. They responded questions such as: "which criteria should be emphasized more in personnel, and how much more?" The responses were presented numerically and scaled on the basis of Saaty's 1-9 scale shown in Table 2. Each pair of criteria is judged only once. A reciprocal value will be automatically assigned to the reverse comparison. Once the pairwise comparisons are completed, the local weight vector $w_{1}$ computed as the unique solution to:

$$
A w_{1}=\lambda_{\max } w_{1}
$$

where $\lambda_{\max }$ is the largest eigenvalue of pairwise comparison matrix $A$. The obtained vector is further normalized by dividing each value by its column total to represent the normalized local weight vector $w_{2}$.

Table 2. Saaty's 1-9 Scale for AHP Preference (Saaty 1996)

\begin{tabular}{cll}
\hline $\begin{array}{c}\text { Intensity of } \\
\text { importance }\end{array}$ & \multicolumn{1}{c}{ Definition } & \multicolumn{1}{c}{ Explanation } \\
\hline 1 & Equal importance & Two activities contribute equally to the objective \\
\hline 3 & Moderate importance & $\begin{array}{l}\text { Experience and judgement slightly favour one over } \\
\text { another }\end{array}$ \\
\hline 5 & Strong importance & $\begin{array}{l}\text { Experience and judgment strongly favour one } \\
\text { over another }\end{array}$ \\
\hline 7 & $\begin{array}{l}\text { Very strong } \\
\text { importance }\end{array}$ & $\begin{array}{l}\text { Activity is strongly favoured and its dominance } \\
\text { is demonstrated in practice }\end{array}$ \\
\hline $2,4,6,8$ & Absolute importance & $\begin{array}{l}\text { Importance of one over another affirmed on the } \\
\text { highest possible order }\end{array}$ \\
\hline $\begin{array}{l}\text { Reciprocal of above } \\
\text { non-zero numbers }\end{array}$ & $\begin{array}{l}\text { if activity } i \text { has one of the above non-zero numbers assigned to it when compared } \\
\text { with activity } j \text {, then } j \text { has the reciprocal value when compared with } i\end{array}$ \\
\hline
\end{tabular}

Step 2: Resolving the effects of the interdependence that exists between the evaluation criteria. The decision makers examine the impact of all the criteria on each other by using pairwise comparisons as well. Questions such as: "which criterion will influence criterion 1 more: criterion 2 or criterion 3 and how much more?" are answered. Various pairwise comparison matrices are formed for each of the criterion. These pairwise comparison matrices 
are needed to identify the relative impacts of criteria interdependent relationships. The normalized principal eigenvectors for these matrices are calculated and shown as column component in interdependence weight matrix of criteria $B$, where zeroes are assigned to the eigenvector weights of the criteria from which a given criterion is given.

Step 3: Now we can obtain the interdependence weights of the criteria by synthesizing the results from previous two steps as follows:

$$
W_{c}=B_{2}^{T} .
$$

There are many studies in the literature using ANP to solve decision making problems. Meade and Sarkis (1999) used ANP to perform logistics and supply chain management analysis. Also in the study performed by Lee and Kim (2000) ANP is used in the interdependent information system project selection process. Besides, Karsak et al. (2002) and Partovi and Corredoira (2002) used ANP in quality function deployment process, while Meade and Presley (2002) used ANP to evaluate alternative research-development projects. Mohanty et al. (2005) employed ANP in project selection problem and ANP is used for location selection (Wu et al. 2009; Lin, Tsai 2010). ANP is used by Yüksel and Dağdeviren (2007) for SWOT analysis, by Dağdeviren et al. (2008) to determine faulty behaviour risks in work systems and by Dağdeviren and Eraslan (2008) to determine priorities in strategic energy policies in Turkey. ANP is also used for selection of dispatching rules in an organization, selection of milling machine and professional selection, respectively (Yazgan et al. 2010; Paramasivam et al. 2011; Kabak et al. 2012).

\subsection{The PROMETHEE method}

The PROMETHEE is a multi-criteria decision-making method introduced by Brans and Vincke (1985), and developed by Brans et al. (1986). It is a quite simple ranking method in conception and application compared with other methods used for multi-criteria analysis. It is well adapted to problems where a finite number of alternatives are to be ranked according to several, sometimes conflicting criteria (Albadvi et al. 2007). The evaluation table is the starting point of the PROMETHEE method. In this table, the alternatives are evaluated according to the different criteria.

The implementation of PROMETHEE requires two additional types of information, namely: (1) Information on the relative importance that is the weights of the criteria considered; (2) Information on the decision-maker's preference function, which he/she uses when comparing the contribution of the alternatives in terms of each separate criterion.

The weights coefficients can be determined according to various methods (Nijkamp et al. 1990; Mergias et al. 2007). ANP method is used to determine the criteria weights in this study.

The PROMETHEE method is appropriate to treat the multi-criteria problem of the following type:

$$
\max \left\{f_{1}(a), f_{2}(a), \ldots, f_{n}(a) \mid a \in A\right\}
$$

where $A$ is a finite set of possible alternatives, and $f_{j}$ denotes $n$ criteria to be maximized. For each alternative, $f_{j}(a)$ is an evaluation of this alternative. When we compare two alternatives 
$a, b \in A$, we must be able to express the result of these comparisons in terms of preference. We, therefore, consider a preference function $P$. The preference function translates the difference between the evaluations of two alternatives ( $a$ and $b$ ) in terms of a particular criterion, into a preference degree ranging from 0 to 1 . Let:

$$
\begin{aligned}
P_{j(a, b)} & =G_{j}\left[f_{j}(a)-f_{j}(b)\right] ; \\
0 & \leq P_{j(a, b)} \leq 1,
\end{aligned}
$$

the preference be function associated to the criterion, $f_{j}(i)$ where $G_{j}$ is a non-decreasing function of the observed deviation $(d)$ between $f_{j}(a)$ and $f_{j}(b)$. In order to facilitate the selection of specific preference function, six basic types of this preference function are proposed to decision maker by Brans and Vincke (1985). These are usual function, U-shape function, V-shape function, level function, linear function and Gaussian function. In each case, one or two parameters (threshold, $q$, $p$ or $s$ ) are needed to be fixed (Brans, Mareschall 1994; Wang, Yang 2007).

Indifference threshold $q$ : the largest deviation to consider as negligible on that criterion. It is a small value with respect to the scale of measurement. Preference threshold $p$ : the smallest deviation to consider decisive in the preference of one alternative over another. It is a large value with respect to the scale of measurement. Gaussian threshold $s$ : it is only used with the Gaussian preference function. It is usually fixed as an intermediate value between indifference and a preference threshold.

PROMETHEE permits the computation of the following quantities for each alternative $a$ and $b$ :

$$
\begin{gathered}
\pi(a, b)=\frac{\sum_{j=1}^{n} w_{j} P_{j}(a, b)}{\sum_{j=1}^{n} w_{j}} ; \\
\phi^{+}(a)=\sum_{x \in A} \pi(x, a) ; \\
\phi^{-}(a)=\sum_{x \in A} \pi(x, a) ; \\
\phi(a)=\phi^{+}(a)-\phi^{-}(a) .
\end{gathered}
$$

For each alternative $a$, belonging to the set $A$ of alternatives, $\pi(a, b)$ is an overall preference index of $a$ over $b$. The leaving flow $\phi^{+}(a)$ is the measure of the outranking character of $a$ (how $a$ dominates all the other alternatives of $A$ ). Symmetrically, the entering flow $\phi^{-}(a)$ gives the outranked character of $a$ (how $a$ is dominated by all the other alternatives of $A$ ). $\phi(a)$ represents a value function, whereby a higher value reflects a higher attractiveness of alternative $a$ and is called net flow.

The three main PROMETHEE tools can be used to analyse the evaluation problem: (1) the PROMETHEE I partial ranking; (2) the PROMETHEE II complete ranking; and (3) the GAIA. 
The PROMETHEE I partial ranking provides a ranking of alternatives. In PROMETHEE I, alternative $a$ is preferred to alternative $b, a P b$, if alternative $a$ has a greater leaving flow than that of alternative $b$ and $a$ smaller entering flow than the entering flow of alternative $b$ :

$$
\begin{aligned}
& a P b \text { if : } \phi^{+}(a)>\phi^{+}(b) \text { and } \phi^{-}(a)<\phi^{-}(b) ; \text { or } \\
& \phi^{+}(a)>\phi^{+}(b) \text { and } \phi^{-}(a)=\phi^{-}(b) ; \text { or } \\
& \phi^{+}(a)=\phi^{+}(b) \text { and } \phi^{-}(a)<\phi^{-}(b) .
\end{aligned}
$$

PROMETHEE I evaluation allows indifference and incomparability situations. Therefore, sometimes partial rankings can be obtained. In the indifference situation ( $a I b)$, two alternatives $a$ and $b$ has the same leaving and entering flows:

$$
a I b \text { if : } \phi^{+}(a)=\phi^{+}(b) \text { and } \phi^{-}(a)=\phi^{-}(b) .
$$

Two alternatives are considered incomparable, $a R b$ if alternative $a$ is better than alternative $b$ in terms of leaving flow, while the entering flows indicate the reverse:

$$
\begin{aligned}
& a R b \text { if: } \phi^{+}(a)>\phi^{+}(b) \text { and } \phi^{-}(a)>\phi^{-}(b) \text {; or } \\
& \phi^{+}(a)<\phi^{+}(b) \text { and } \phi^{-}(a)<\phi^{-}(b) .
\end{aligned}
$$

PROMETHEE II provides a complete ranking of the alternatives from the best to the worst one. Here, the net flow $(\phi)$ is used to rank the alternatives. The alternative with the higher net flow is assumed to be superior. Since PROMETHEE I does not provide a complete ranking, resulting ranking cannot be compared with the ranking provided by PROMETHEE II. PROMETHEE I ensure creation of indifferent and incomparable alternatives. In some ranking problems, PROMETHEE I can give a complete ranking depending on the evaluation matrix values and, this ranking cannot be different from the one achieved with PROMETHEE II.

The GAIA plane displays the relative position of the alternatives graphically, in terms of contributions to the various criteria (Brans, Vincke 1985; Brans, Mareschall 1994). Principal components analysis is applied to the matrix of "normed flows", defined for alternative $a$ and criterion $j$ by:

$$
\phi_{j}(a)=\frac{1}{n-1} \sum_{b \neq a}\left[P_{j}(a, b)-P_{j}(b, a)\right]
$$

where $n$ is the number of alternatives, and this is used to generate a two-dimensional plot in which the alternatives and criteria are represented in the same plan (Belton, Stewart 2002).

There are some studies in the literature which consider the PROMETHEE. Goumas and Lygerou (2000) used the PROMETHEE method in the ranking of alternative energy exploitation projects. In addition to these studies Wang and Yang (2007), for information systems outsourcing; Mergias et al. (2007), for the selection of the best compromise management scheme for end of life vehicles; Araz et al. (2007) in the outsourcing management, used PROMETHEE method. Lin (2008) used SOM and PROMETHEE techniques for 
earthquake-induced landslide hazard monitoring and assessment in Central Taiwan. Cavalcante et al. (2010) developed a preventive maintenance decision model based on PROMETHEE II integrated with Bayesian approach.

\section{The proposed hybrid MCDM approach}

The suggested approach for the university selection includes the steps as following:

Step 1: Identify the factors and sub-factors to be used in the model.

Step 2: Structure the ANP model hierarchically (goal, factors, sub-factors).

Step 3: Determine the local weights of the factors and sub-factors by using pairwise comparison matrices. The scale regarding relative importance to measure the relative weights is given Table 2 . The relative importance values are determined with Saaty's $1-9$ scale, where a score of 1 represents equal importance between the two elements and a score of 9 indicates the extreme importance of one element (row component in the matrix) compared to the other one (column component in the matrix) (Meade, Sarkis 1999).

Step 4: Determine the inner dependence matrix of each factor with respect to the other factors. This inner dependence matrix is multiplied with the local weights of the factors, determined in Step 3, to compute the interdependent weights of the factors.

Step 5: Calculate the global weights for the sub-factors. Global sub-factor weights are computed by multiplying local weight of the sub-factor with the interdependent weights of the factor to which it belongs.

Step 6: Preference functions and parameters to be used for PROMETHEE computations are determined by the decision making team.

Step 7: After the approval of the functions, partial ranking with PROMETHEE I and complete ranking with PROMETHEE II are determined.

Step 8: GAIA plane are determined. Decision Lab software is used at the steps 6, 7 and 8.

At the end of the proposed procedure, the best university is selected according to the rankings and GAIA plane obtained by PROMETHEE I and II. Schematic representation of the proposed approach is presented in Fig. 1.

\section{An application of the proposed model}

In this study, the application of proposed model which illustrates Turkish higher education system is performed in Turkey. Nine public and six private universities, examples of 105 public and 61 private ones totally, which have department of industrial engineering from different geographic location were taken into account to rank. In the application phase, an expert team is established by five lecturers in different faculties, including the authors of this paper. Factors shown in Table 1 are clarified as a result of literature review and organized by authors, given to approximately 50 university students in a questionnaire. In the questionnaire, the factors are graded from 1 to 10 points scale according to their importance. 18 factors are chosen according the grades which are given by students and 4 factors that are under the limit omitted from the questionnaire. The omitted factors are "relatives living in the area", "speedy approval of visa", "athletic ranking or reputation", "religious activities", respectively. Relatives living in the same 


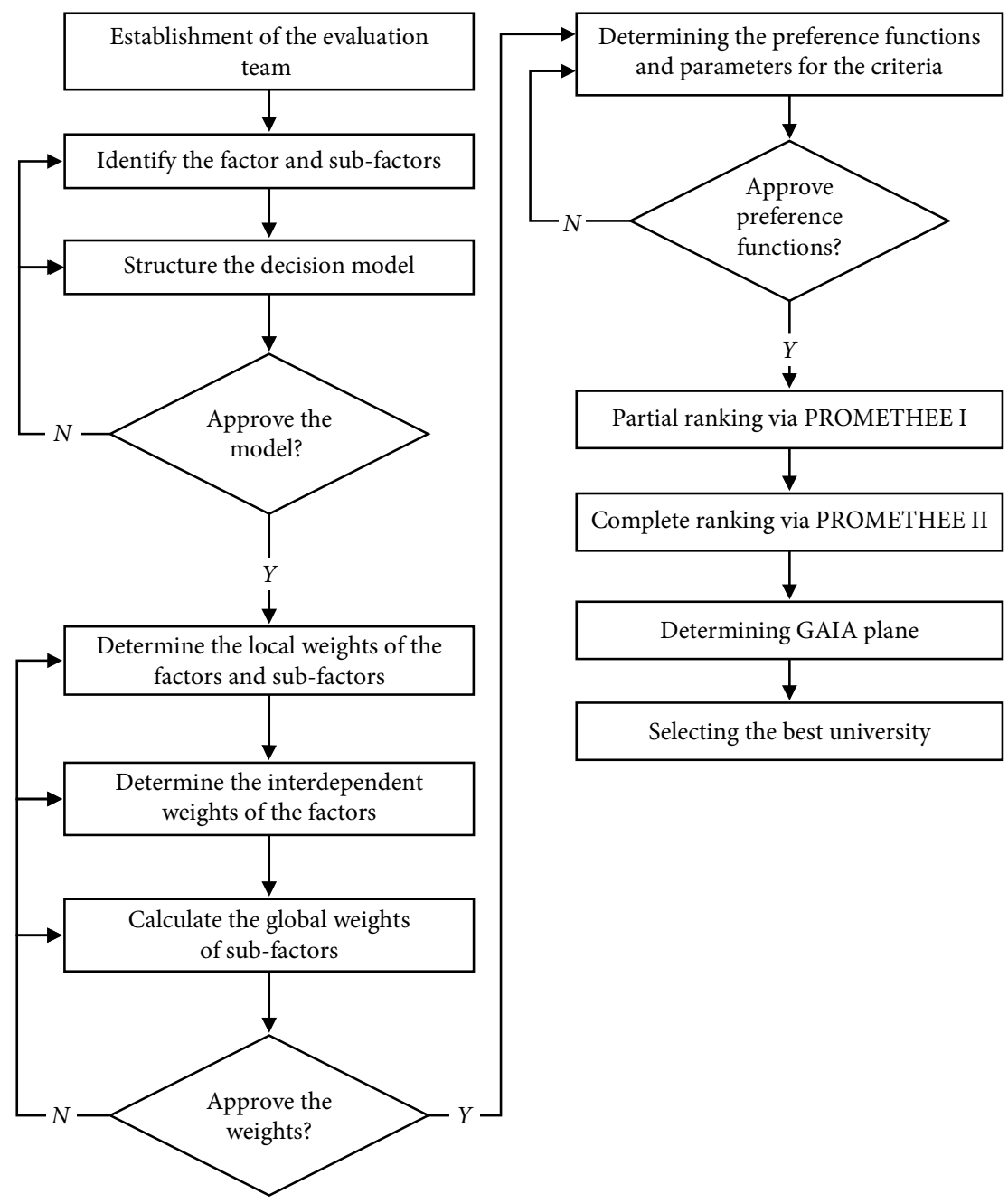

Fig. 1. The flowchart of the proposed model for university selection

city with university can make life easier for students. Despite speedy approval of visa is critical for foreign students, the factor does not get the enough score to be placed in the questionnaire. "Athletic ranking or reputation" and "religious activities" aren't common factors and may be important for some special students. The factors and sub-factors that are chosen by students to be used in the model were grouped by an expert team according to the literature, especially Warwick and Mansfield's study (2004) and first questionnaire results.

Pairwise comparison matrices are used to calculate the factor and sub-factor weights that are also formed by the same team. Although totally of 350 surveys delivered, 220 usable questionnaires are received as a feedback. We see that response rate is $62.9 \%$. The application is performed based on the steps provided in previous section and explained step by step together with the results. 
Step 1: The factors and sub-factors used to evaluate universities are determined in this step. Factors searched in literature by authors and grouped by the expert team are used in the study. Table 3 shows the factors and the sub-factors concerned.

Step 2: The ANP model formed by the factors and sub-factors determined in the first step is shown in Fig. 2.

Table 3. Factors of proposed model for university selection

\begin{tabular}{|c|c|c|}
\hline Factor & Sub-factors & Abb. \\
\hline \multirow{4}{*}{ Academic } & Reputation of university & RU \\
\hline & Quality of faculty & QF \\
\hline & Quality of program & QP \\
\hline & Courses studied & CS \\
\hline \multirow{5}{*}{ Social } & Future career prospects and opportunities & FCPO \\
\hline & University's social life & USL \\
\hline & Surrounding communities & SC \\
\hline & Family, peer and teacher's influence & FPTI \\
\hline & Information supplied by universities & ISU \\
\hline \multirow{6}{*}{ Physical } & Campus & $\mathrm{C}$ \\
\hline & Geographic location of university & GLU \\
\hline & Institution's infrastructure & II \\
\hline & Local infrastructure & LI \\
\hline & Foreign language requirements & FLR \\
\hline & Reputation for disabled & $\mathrm{RD}$ \\
\hline \multirow{3}{*}{ Financial } & Tuition (university) fees & TF \\
\hline & Scholarship (financed by governmental or non-governmental organizations) & S \\
\hline & Living expenses in the campus/city, accommodation & LECA \\
\hline
\end{tabular}

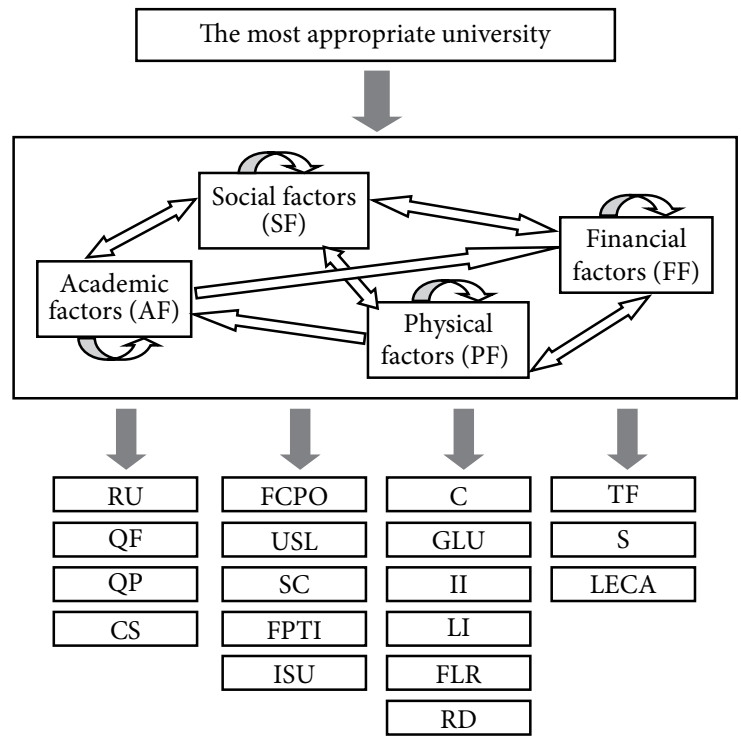

Fig. 2. The proposed ANP model for university selection 
ANP model is composed of 3 stages. The first step includes the objective of the model, determined as "choose the most appropriate university". The second step includes the factors to be used in the measurement of university preference. The factors of second stage are connected to the goal with a single directional arrow. The arrows in the second stage represent the interdependence among the factors. The interdependencies among factors which are in this stage are taken into account and by this way the effects of the factors on each other are analysed. The arrow from social factor to academic factor means social factor effects academic factor; academic factor is affected by academic, social and physical factors. Sub-factors related to the factors are in the third stage of the model and the factors determined in Step 1 are also in this stage.

Step 3: In this step, local weights of the factors and sub-factors which take part in the second and third levels of ANP model are calculated. Pairwise comparison matrices are formed by the expert team by using the scale given in Table 1. For example academic factors are compared with social factors using the question "Which is considered more important by the student choosing the university, and how much more important is it with respect to satisfaction with the university?" All the evaluation matrices are produced in the same manner. Pairwise comparison matrices for factors and sub-factors are given in Tables 4-8 together with the calculated local weights and consistency index. If the value of Inconsistency Ratio is smaller or equal to $10 \%$, the inconsistency is acceptable. If the Inconsistency Ratio (IR) is greater than $10 \%$, we need to revise the subjective judgment.

Table 4. Local weights and pairwise comparison matrix of factors

\begin{tabular}{llllll}
\hline Factors & AF & SF & PF & FF & Weights \\
\hline AF & 1 & 1.13 & 1.32 & 1.02 & 0.273 \\
\hline SF & 0.885 & 1 & 1.98 & 1.6 & 0.318 \\
\hline PF & 0.758 & 0.505 & 1 & 1.07 & 0.196 \\
\hline FF & 0.98 & 0.625 & 0.935 & 1 & 0.214 \\
\hline
\end{tabular}

$\mathrm{IR}=0.018$

Table 5. Local weights and pairwise comparison matrix of academic sub-factors

\begin{tabular}{lllllc}
\hline A sub-factors & RU & QF & QP & CS & Weights \\
\hline RU & 1 & 0.86 & 0.9 & 2.38 & 0.271 \\
\hline QF & 1.163 & 1 & 1.39 & 2.61 & 0.334 \\
\hline QP & 1.111 & 0.719 & 1 & 2.47 & 0.277 \\
\hline CS & 0.42 & 0.383 & 0.405 & 1 & 0.118 \\
\hline
\end{tabular}

$\mathrm{IR}=0.004$

Table 6. Local weights and pairwise comparison matrix of social sub-factors

\begin{tabular}{lllllll}
\hline S sub-factors & FCPO & USL & SC & FPTI & ISU & Weights \\
\hline FCPO & 1 & 3.42 & 3.04 & 2.59 & 3.03 & 0.417 \\
\hline USL & 0.292 & 1 & 2.29 & 1.06 & 2.63 & 0.201 \\
\hline SC & 0.329 & 0.437 & 1 & 0.86 & 1.22 & 0.12 \\
\hline FPTI & 0.386 & 0.943 & 1.163 & 1 & 1.89 & 0.163 \\
\hline ISU & 0.33 & 0.38 & 0.82 & 0.529 & 1 & 0.098 \\
\hline
\end{tabular}

$\mathrm{IR}=0.027$ 
Table 7. Local weights and pairwise comparison matrix of physical sub-factors

\begin{tabular}{lllllllc}
\hline P sub-factors & C & GLU & II & LI & FLR & RD & Weights \\
\hline C & 1 & 1.74 & 1.34 & 0.63 & 1.17 & 0.96 & 0.181 \\
\hline GLU & 0.575 & 1 & 1.3 & 0.71 & 1.12 & 0.82 & 0.147 \\
\hline II & 0.746 & 0.769 & 1 & 0.69 & 0.78 & 1.05 & 0.136 \\
\hline LI & 1.587 & 1.408 & 1.449 & 1 & 1.18 & 0.99 & 0.206 \\
\hline FLR & 0.855 & 0.893 & 1.282 & 0.847 & 1 & 1.25 & 0.166 \\
\hline RD & 1.042 & 1.22 & 0.952 & 1.01 & 0.8 & 1 & 0.164 \\
\hline
\end{tabular}

$\mathrm{IR}=0.014$

Table 8. Local weights and pairwise comparison matrix of financial sub-factors

\begin{tabular}{lllll}
\hline F sub-factors & TF & \multicolumn{1}{c}{$S$} & LECA & Weights \\
\hline TF & 1 & 0.43 & 0.77 & 0.214 \\
\hline $\mathrm{S}$ & 2.326 & 1 & 2.05 & 0.52 \\
\hline LECA & 1.299 & 0.488 & 1 & 0.266 \\
\hline
\end{tabular}

$\mathrm{IR}=0.002$

Step 4: In this step, interdependent weights of the factors were calculated and the dependencies among the factors were considered. Dependence among the factors was determined by analysing the impact of each factor on every other factor using pairwise comparisons. The dependencies between factors are shown at the second stage in Fig. 2. These dependencies were determined by an expert team on the basis of a group study and following statements were obtained: a) "academic factors" affect "academic and financial factors"; b) there is an interdependency between "academic factors" and "social factors"; c) "social factors" affect "social factors"; d) there is an interdependency between "social factors" and "physical, financial factors"; e) "financial factors" affect "financial factors"; f) there is an interdependency between "financial factors" and "physical factors"; g) "physical factors" have an effect on "physical and academic factors".

Based on the dependencies presented above, expert team defined dependence among all factors via pairwise comparison matrices. For this purpose, four pairwise comparison matrices were formed for AF, SF, PF and FF factors. The resulting relative importance weights of these matrices were calculated. These weights are listed in Table 9, separately for each factor. "0" values presented in Table 9 mean that there is no dependence between two factors and the numerical values show the degree of relative impact between two factors. For example, the SF's degree of relative impact for AF is 0.423 .

Relative importance of the criteria on the basis of interdependence can be calculated by using the data given in Tables 4 and 9 as follows:

$$
w_{\text {factors }}=\left[\begin{array}{l}
\mathrm{AF} \\
\mathrm{SF} \\
\mathrm{PF} \\
\mathrm{FF}
\end{array}\right]=\left[\begin{array}{cccc}
0.321 & 0.249 & 0 & 0.241 \\
0.423 & 0.404 & 0.406 & 0.329 \\
0.256 & 0.165 & 0.323 & 0.234 \\
0 & 0.182 & 0.271 & 0.271
\end{array}\right] \times\left[\begin{array}{l}
0.273 \\
0.318 \\
0.196 \\
0.214
\end{array}\right]=\left[\begin{array}{l}
0.218 \\
0.393 \\
0.236 \\
0.153
\end{array}\right] .
$$


Table 9. Degree of relative impact for factors

\begin{tabular}{cllll}
\hline & AF & SF & PF & FF \\
\hline AF & 0.321 & 0.249 & 0 & 0.241 \\
\hline SF & 0.423 & 0.404 & 0.406 & 0.329 \\
\hline PF & 0.256 & 0.165 & 0.323 & 0.234 \\
\hline FF & 0 & 0.182 & 0.271 & 0.197 \\
\hline
\end{tabular}

According to the calculation made, SF is determined as the most important considering criteria relating to university preference. Significant differences are observed in the results obtained for the criteria priorities when interdependent priorities of the criteria $\left(w_{\text {factors }}\right)$ and dependencies are not taken into account. For example, the results change from 0.273 to $0.218,0.318$ to $0.393,0.196$ to 0.236 and 0.214 to 0.153 for the factors weight values of factors AF, SF, PP and FF, respectively.

Step 5: Using interdependent weights of the factors and local weights sub-factors, global weights for the sub-factors are calculated in this step. Global sub-factor weights are computed by multiplying local weight of the sub-factor with the interdependent weight of the factor to which it belongs. Computed global weights for sub-factors are shown in Table 10.

According to Table 10, the three most important sub-factors to university preference are "FCPO-Future career prospects and opportunities", "S-Scholarship" and "USL-University's social life", respectively.

Step 6: In this step, firstly alternative universities are evaluated based on the evaluation criteria and the evaluation matrix is formed. The evaluations of these fifteen alternatives according to the previously stated criteria, i.e. evaluation matrix, are displayed in Table 11.

Table 10. Computed global weights for sub-factors

\begin{tabular}{|c|c|c|c|}
\hline Factors and local weights & Sub-factors & Local weights & Global weights \\
\hline \multirow{4}{*}{$\mathrm{AF}(0.218)$} & RU & 0.271 & 0.059 \\
\hline & QF & 0.334 & 0.073 \\
\hline & QP & 0.277 & 0.060 \\
\hline & CS & 0.118 & 0.026 \\
\hline \multirow{5}{*}{ SF (0.393) } & FCPO & 0.417 & 0.164 \\
\hline & USL & 0.201 & 0.079 \\
\hline & SC & 0.120 & 0.047 \\
\hline & FPTI & 0.163 & 0.064 \\
\hline & ISU & 0.098 & 0.039 \\
\hline \multirow{6}{*}{$\mathrm{PF}(0.236)$} & C & 0.181 & 0.043 \\
\hline & GLU & 0.147 & 0.035 \\
\hline & II & 0.136 & 0.032 \\
\hline & LI & 0.206 & 0.049 \\
\hline & FLR & 0.166 & 0.039 \\
\hline & $\mathrm{RD}$ & 0.164 & 0.039 \\
\hline \multirow{3}{*}{$\mathrm{FF}(0.153)$} & TF & 0.214 & 0.033 \\
\hline & $\mathrm{S}$ & 0.520 & 0.080 \\
\hline & LECA & 0.266 & 0.041 \\
\hline
\end{tabular}




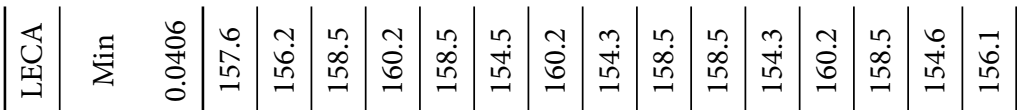

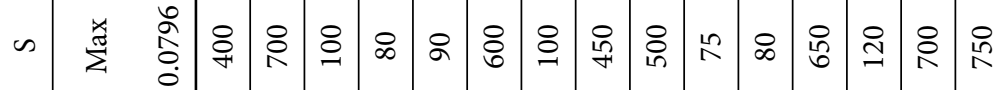

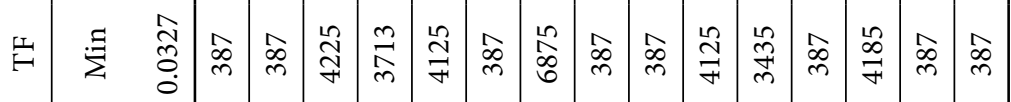

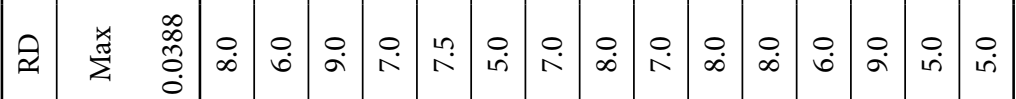

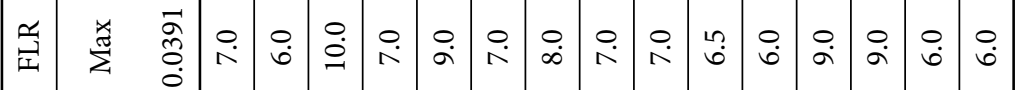

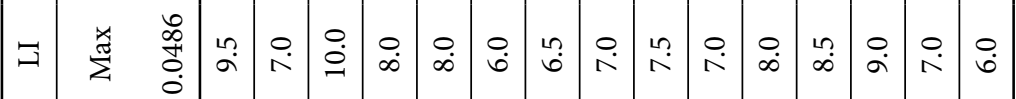

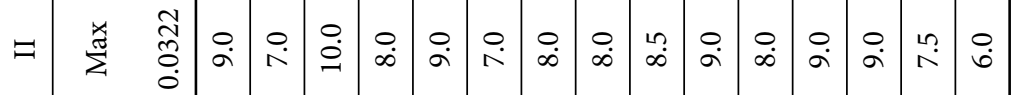

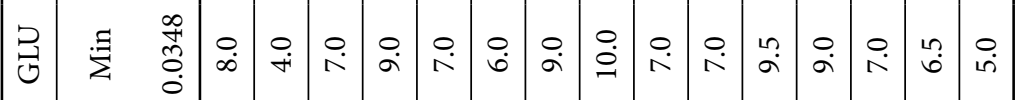

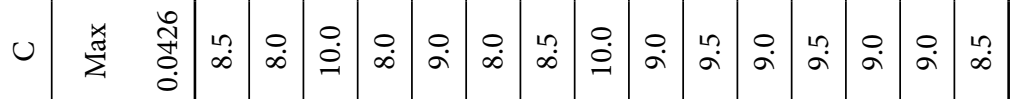

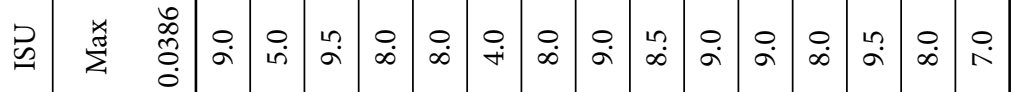

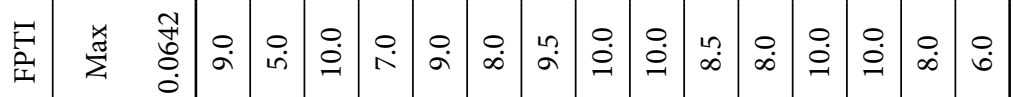

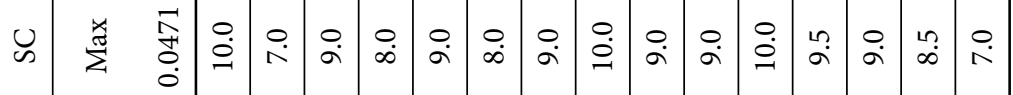

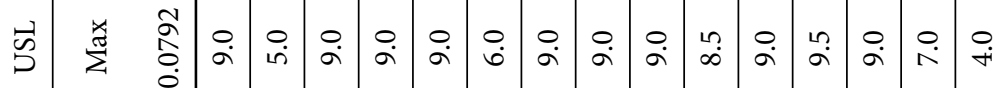

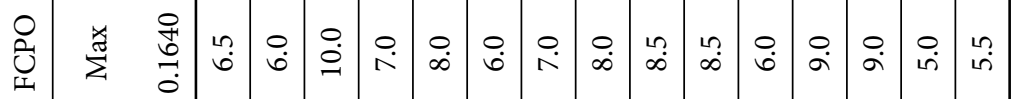

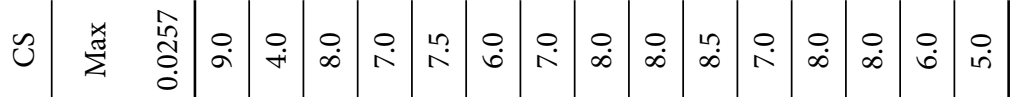

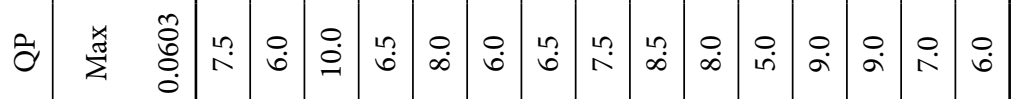

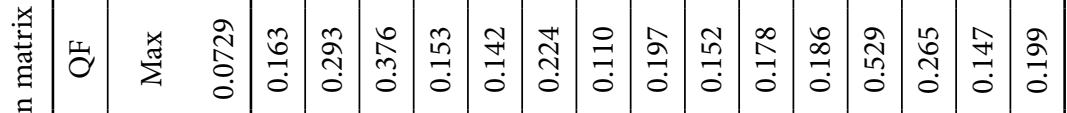

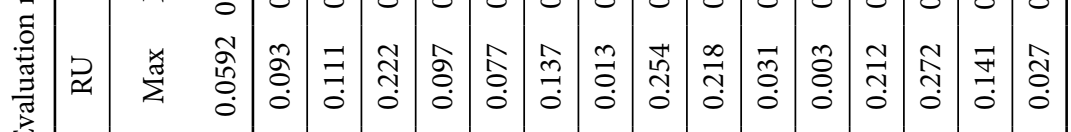

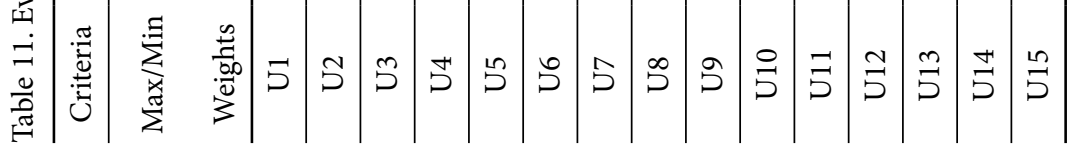


Before using the PROMETHEE method to rank the alternative universities, for each criterion, a specific preference function (PF) with its thresholds is defined. Preference functions and threshold values have been defined by the expert team established at the beginning of the application. Despite that preference functions and threshold values have been defined by the expert team in this paper, every student reading this paper and understanding the methodology must define his own values in his university evaluation process. LECA values were picked from Turkish Statistical Institute's official reports (TUIK 2008) while RU, QF and TF values were calculated according to the ÖSYM's declarations (ÖSYM 2009). Decision-making team has set the other values 1 through 10 by taking into consideration the features of alternative universities. The preference functions and thresholds defined are provided in Table 12. Since different preference functions, number of criteria and alternatives make calculations difficult in PROMETHEE method, a software program like Decision Lab is used.

Step 7: After evaluation matrix and preference functions are determined, alternative universities are evaluated by using Decision Lab software. The positive flow $\left(\phi^{+}\right)$, negative flow $\left(\phi^{-}\right)$and net flow $(\phi)$ values obtained from this evaluation are given in Table 13.

By using the flow values in Table 13, firstly the partial ranking is determined via PROMETHEE I as shown in Fig. 3. PROMETHEE I used positive and negative flow values to find the partial ranking.

Table 12. Preference functions

\begin{tabular}{|c|c|c|c|c|c|c|c|}
\hline \multirow{2}{*}{ Criteria } & \multirow{2}{*}{ PF } & \multicolumn{6}{|c|}{ Thresholds } \\
\hline & & $q$ & $p$ & $s$ & $r$ & $m$ & $\sigma$ \\
\hline $\mathrm{RU}$ & Gaussian & & & & & & 0.127 \\
\hline QF & Gaussian & & & & & & 0.221 \\
\hline $\mathrm{QP}$ & Gaussian & & & & & & 7 \\
\hline $\mathrm{CS}$ & Linear & & & 5 & 10 & & \\
\hline FCPO & V-shape & & & & & 7 & \\
\hline USL & Gaussian & & & & & & 6 \\
\hline SC & Gaussian & & & & & & 8 \\
\hline FPTI & Gaussian & & & & & & 6 \\
\hline ISU & Level & 5 & 9 & & & & \\
\hline $\mathrm{C}$ & Level & 5 & 9 & & & & \\
\hline GLU & Linear & & & 5 & 8 & & \\
\hline II & Linear & & & 5 & 9 & & \\
\hline LI & Linear & & & 5 & 9 & & \\
\hline FLR & Linear & & & 5 & 9 & & \\
\hline $\mathrm{RD}$ & V-shape & & & & & 8 & \\
\hline $\mathrm{TF}$ & Linear & & & 500 & 5000 & & \\
\hline $\mathrm{S}$ & Linear & & & 400 & 700 & & \\
\hline LECA & Linear & & & 143 & 162 & & \\
\hline
\end{tabular}


Table 13. PROMETHEE results

\begin{tabular}{cccc}
\hline Alternatives & $f^{+}$ & $\phi^{-}$ & $f$ \\
\hline $\mathrm{U}-1$ & 0.0353 & 0.0469 & -0.0116 \\
\hline $\mathrm{U}-2$ & 0.0585 & 0.0822 & -0.0237 \\
\hline $\mathrm{U}-3$ & 0.1372 & 0.0327 & 0.1044 \\
\hline $\mathrm{U}-4$ & 0.0241 & 0.0780 & -0.0538 \\
\hline $\mathrm{U}-5$ & 0.0398 & 0.0637 & -0.0238 \\
\hline $\mathrm{U}-6$ & 0.0324 & 0.0869 & -0.0545 \\
\hline $\mathrm{U}-7$ & 0.0214 & 0.1017 & -0.0803 \\
\hline $\mathrm{U}-8$ & 0.0814 & 0.0162 & 0.0652 \\
\hline $\mathrm{U}-9$ & 0.0815 & 0.0162 & 0.0654 \\
\hline $\mathrm{U}-10$ & 0.0466 & 0.0650 & -0.0183 \\
\hline $\mathrm{U}-11$ & 0.0164 & 0.1023 & -0.0860 \\
\hline $\mathrm{U}-12$ & 0.1585 & 0.0088 & 0.1497 \\
\hline $\mathrm{U}-13$ & 0.1042 & 0.0341 & 0.0701 \\
\hline $\mathrm{U}-14$ & 0.0511 & 0.0891 & -0.0380 \\
\hline $\mathrm{U}-15$ & 0.0483 & 0.1129 & -0.0647 \\
\hline
\end{tabular}

Value of $\phi^{+}=(\mathrm{U} 12)=0.1585>\phi^{+}(\mathrm{U} 3)=0.1372, \phi^{-}(\mathrm{U} 12)=0.0088<\phi^{-}(\mathrm{U} 3)=0.0327$ and alternative U12 is preferred to alternative U3 according to Eq. (10). U3 and U9 are incomparable alternatives according to Eq. (12) and net flows for U3 and U9 are required. $\phi(\mathrm{U} 3)=\phi^{+}(\mathrm{U} 3)-\phi^{-}(\mathrm{U} 3)=0.1372-0.0327=0.1044$ and $\phi(\mathrm{U} 9)=\phi^{+}(\mathrm{U} 9)-\phi^{-}(\mathrm{U} 9)=$ $0.0815-0.0162=0.0654$ are calculated. Finally, U9 is preferred to U3. According to the Fig. 3, $\mathrm{U}-12$ is determined as the best alternative according to the PROMETHEE I partial ranking. U-3, U-13, U-1, U-4, U-7, U-10, U-6 and U-9, U-8, U-2, U-5, U-14 alternatives are preferred to $\mathrm{U}-11$ alternative. $\mathrm{U}-12, \mathrm{U}-9, \mathrm{U}-8, \mathrm{U}-2, \mathrm{U}-14$ and $\mathrm{U}-3, \mathrm{U}-13$ alternatives are preferred to $\mathrm{U}-15$ alternative. On the other hand $\mathrm{U}-3$ and $\mathrm{U}-13$ are incomparable with $\mathrm{U}-9$ and $\mathrm{U}-8$. U-1, U-10, U-2, U-5 (also U-4, U-6, U-14 and U-7, U-15) are incomparable alternatives. PROMETHEE I did not provide information about the worst alternative.

Net flow values given in the last column of Table 13, are used in PROMETHEE II complete ranking to identify the worst alternative as shown in Fig. 4.

According to the Fig. 4, U-12 is selected as the best alternative based on the information PROMETHEE II provides, and the other alternatives are ranked in the order of U-3, U-13, U-9, U-8, U-1, U-10, U-2, U-5, U-14, U-4,U-6, U-15, U-7, U-11.

Step 8: The decision problem can be represented in the GAIA plane where alternative universities are represented by points and criteria by vectors. In this way, conflicting criteria may appear clearly. Criteria vectors expressing similar preferences on the data are oriented in the same direction, while conflicting criteria are pointing in opposite directions. The length of each vector is a measure of its power in alternative universities differentiation.

This plane is the result of principal component analysis (PCA), projecting the 18-dimensional space of criteria onto a two-dimensional plane, i.e. the 18 original variables are transformed to the two new variables that are obtained by two linear combinations of the original variables. In 


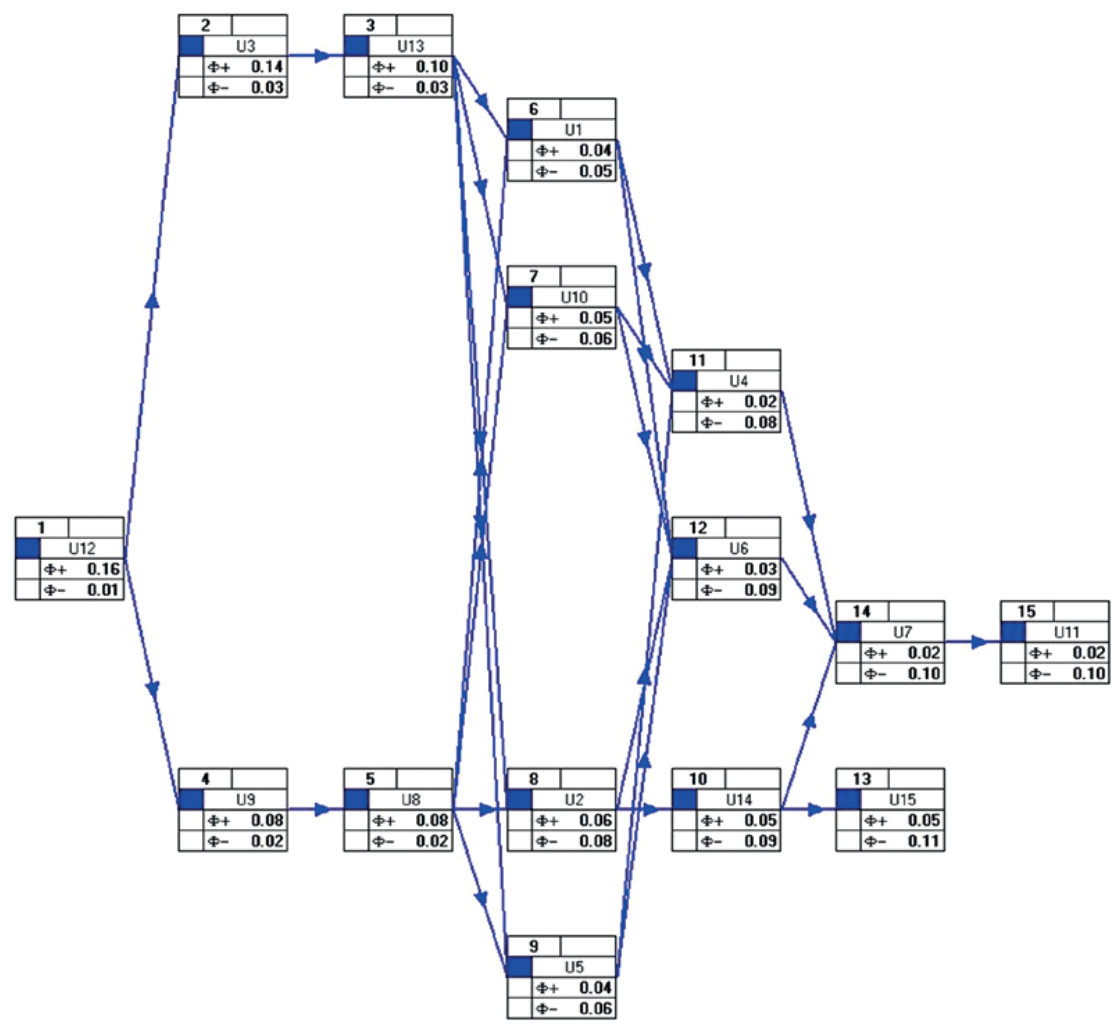

Fig. 3. PROMETHEE I partial ranking

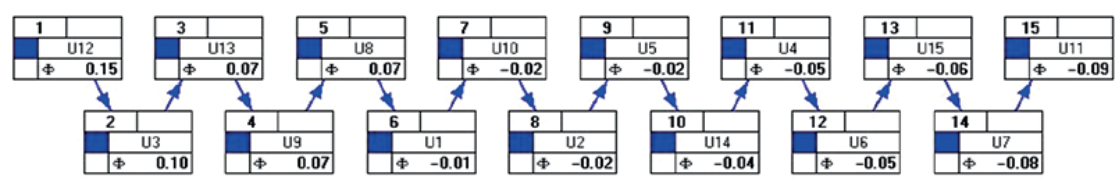

Fig. 4. PROMETHEE II complete ranking

the PCA process, criteria are handled by the linear combinations to prevent double counting (Albadvi et al. 2007). As it is shown in the Fig. 5, the Delta-parameter is $85.28 \%$; this means only $14.72 \%$ of the total information gets lost by the projection.

We observe that RU (Reputation of university) and TF (Tuition fees) have a high differentiation power and expresses independent preferences, different from those expressed by most of all other criteria. A cluster of conflicting criteria (RD and S expressing opposite preferences) are clearly represented. It is also possible to appreciate clearly the quality of the alternative universities with respect to the different criteria. U12 is particularly good on RU and QF. U-3 and U-13 are good on RD and FCPO. 


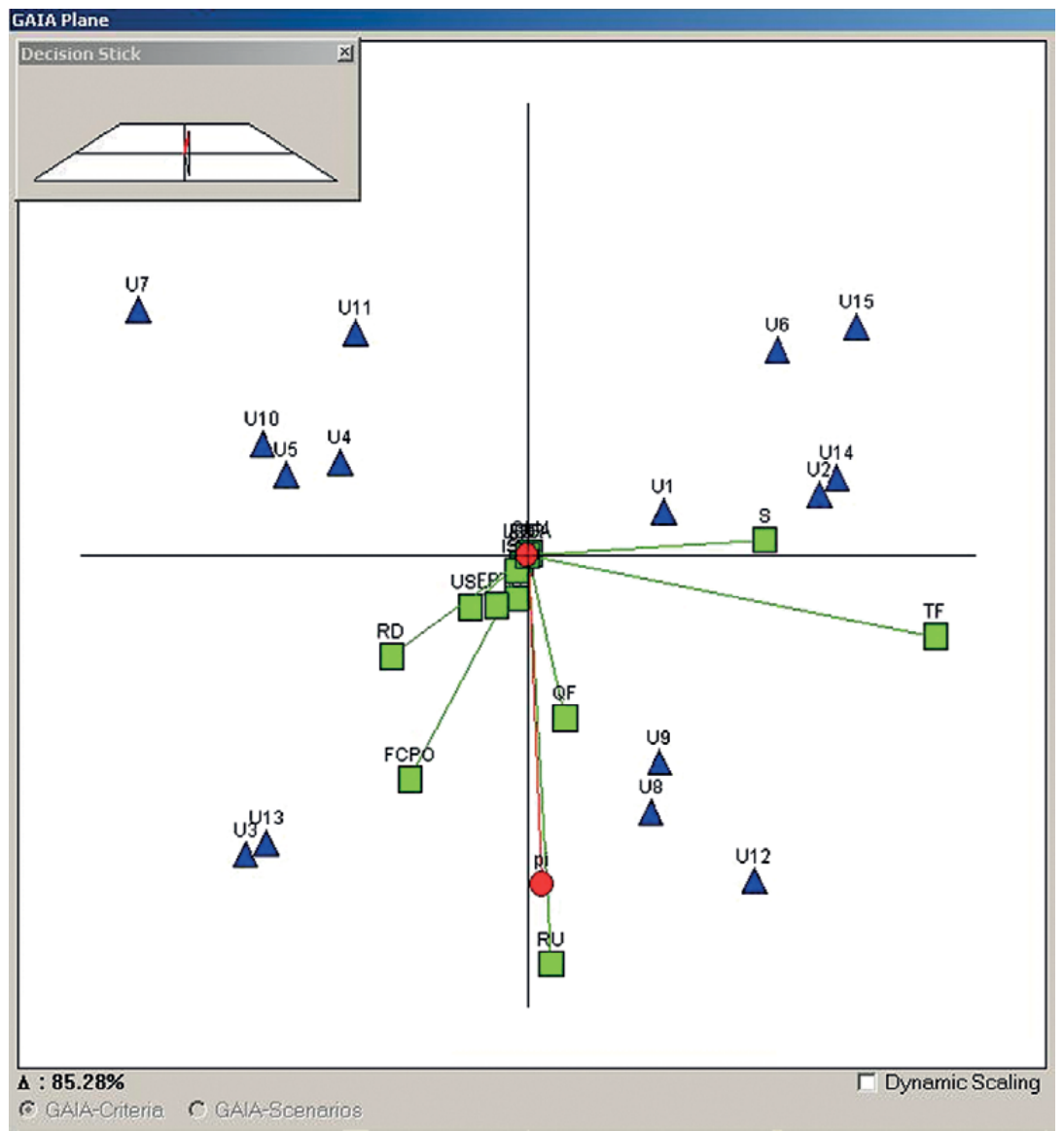

Fig. 5. GAIA plane for university selection

Vector pi (decision axis) represents the direction of the compromise derived from the assignment; the decision maker is invited to appreciate the alternative universities located in that direction (Wang, Yang 2007). It can be seen from Fig. 5 that pi vector is in the direction of criterion RU-criterion QF and the closest alternatives to the pi vector are U-12, U-9, U-8, U-13 and U-3. This result is consistent with the complete ranking of PROMETHEE II.

According to the ANP and PROMETHEE computations, it is decided to prefer U-12, U-3, U-13 and U-9 respectively. Variations in the weights of criteria and their affects to the ranking are analysed. Sensitivity analysis has been performed with Decision Lab Software and the resulting "stability intervals" values are given in Table 14. Table 14 gives for each criterion the limits within weights' values which can vary without changing the PROMETHEE II complete ranking. From the result of sensitivity analysis, it is clear that FCPO, USL, RU and QF have the greatest impacts on the complete ranking. Although this study has been conducted in the context of Turkey, it nonetheless has relevance across all universities. It suggests the importance of informed university and student recruitment practice for all universities in order to ensure recruitment and retention of quality students. 
Table 14. Stability intervals

\begin{tabular}{llcc}
\hline \multirow{2}{*}{ Criteria } & \multirow{2}{*}{ Weight } & \multicolumn{2}{c}{ Interval } \\
\cline { 3 - 4 } & & Min & Max \\
\hline RU & 0.059 & 0.0580 & 0.0611 \\
\hline QF & 0.073 & 0.0722 & 0.0777 \\
\hline QP & 0.060 & 0.0518 & 0.0630 \\
\hline CS & 0.026 & 0.0000 & Infinity \\
\hline FCPO & 0.164 & 0.1611 & 0.1645 \\
\hline USL & 0.079 & 0.0739 & 0.0799 \\
\hline SC & 0.047 & 0.0000 & 0.0509 \\
\hline FPTI & 0.064 & 0.0375 & 0.0649 \\
\hline ISU & 0.039 & 0.0285 & 0.1806 \\
\hline C & 0.043 & 0.0000 & Infinity \\
\hline GLU & 0.035 & 0.0308 & 0.1838 \\
\hline II & 0.032 & 0.0000 & Infinity \\
\hline LI & 0.049 & 0.0000 & Infinity \\
\hline FLR & 0.039 & 0.0000 & Infinity \\
\hline RD & 0.039 & 0.0361 & 0.0395 \\
\hline TF & 0.033 & 0.0325 & 0.0338 \\
\hline S & 0.080 & 0.0794 & 0.0813 \\
\hline LECA & 0.041 & 0.0000 & Infinity \\
\hline
\end{tabular}

According to the obtained results, Turkish universities should emphasize the following criteria future career prospects and opportunities (FCPO), scholarship (S), university's social life (USL), quality of faculty (QF) and quality of program (QP), respectfully. They will be very useful in the decision process for the students. Students' preferences never existed before when state universities are much fewer and students who could not enrol in them are forced to go to private universities or even further their education abroad. Since the number of students finishing high school has stood similar for some time while the number of universities has increased rapidly, to 166 at present in Turkey.

The changing situation forces universities to get new strategies that this study presents some directions to them. A university has to be planned as a place where students think they can learn what they need and enjoy their life during the education. Greater emphasis should be placed on academic reputation, bursaries, faculty and program qualities in the brochures and university's web pages to attract students.

By the way, international programs which will certainly provide more opportunities in future are a magnet, particularly for students who want to learn a foreign language in their own country. Competition especially for best students is fierce and international programs, satisfactory opportunities after graduation or job placement can be a real advantage for universities wanting to attract these students to their own campuses.

Students from poor families must be encouraged to apply to top universities. Universities could offer a free foundation year, discounted accommodation, bursary and a fee waiver or discount. It also creates a genuinely fair playing field for all students. 
Even though private universities maintain their fee levels, it cannot be enough to get brilliant students. The situation forces them to take extra action to convince students. Universities may spend an amount of money on public relations and advertisement to expand their student base. Another promising change might be an opening of Turkish universities' doors to more foreign students, whose numbers have increased in every year throughout the world.

Finally, attracting an application is only the first challenge for universities, the risk of losing a student due to poor course selection, unrealistic or over-optimistic expectations can jeopardize the relationship, with significant financial consequences for both parties. Using experienced counsellors who are skilled in advising students helps ensure that these scenarios are rare.

\section{Conclusions}

In this paper, a decision-making approach is provided for university selection problem that is based on the comparisons of university alternatives according to identified criteria. PROMETHEE and ANP compound decision-making methods have been used in proposed approach. With its above-mentioned structure, the proposed approach differs from the present university selection literature that uses statistical methods. In this paper, ANP is used to assign weights to the criteria to be used in university selection, while PROMETHEE is employed to determine the priorities of the alternatives. The weights obtained from ANP are included in decision making process by using them in PROMETHEE computations and the alternative priorities are determined based on these weights. By this way, weighting of the criteria considered during decision-making and evaluation of these criteria via preference functions are performed simultaneously.

The proposed decision-making approach can help decision-makers to choose and analyse factors and attributes easily. In addition, the strengths of this approach over the existing methods can be explained as follows. The PROMETHEE takes into account the preference function of each criterion, determined by the decision-makers. By this way, each criterion is evaluated on a different basis and it is possible to make better decisions. PROMETHEE I identifies the alternatives which cannot be compared and the alternatives which are indifferent, by making a partial ranking, while PROMETHEE II provides a complete ranking for alternatives. GAIA plane is a useful tool to evaluate a decision making problem. It gives beneficial information about alternatives and criteria. For example, in university evaluation, U-8, U-9 and U-12 are the same on some criteria and U-1, U-2 and U-14 are the same on other criteria. In addition, differentiation power of the criteria, similar criteria, independent criteria, and opposite criteria can be determined from the GAIA analysis. By utilizing the PROMETHEE method to make sensitivity analysis of the result, the most effective criteria in decision making are determined. These opportunities are not available in present methods such as AHP, fuzzy AHP, ELECTRE and TOPSIS. The proposed model has only been implemented on a university selection problem including 15 universities in Turkey; however, experts on education have found the proposed model satisfactory and implementable in others education selection decisions. 
Since the parameters related with the criteria included in the model in university selection, in this study these parameters have been able to be determined as crisp parameters, classical ANP and PROMETHEE have been used. The proposed integrated approach might be incapable if the evaluation matrix for the alternatives cannot be formed with crisp values. Some criteria could have a qualitative structure or have an uncertain structure which cannot be measured precisely. In such cases, fuzzy numbers can be used to obtain the evaluation matrix.

Some students, particularly those from low family income, are choosing to live at home during their university education. Their choice of university was constrained by the cost of going to university. However, the constraint was more frequent among students from lower class families than those from middle- and upper-class backgrounds. Private universities that wish to attract more disadvantaged students might want to direct bursaries at high-performing students from far areas. Future researches may try to explain the association between indicators of social class background and choice of university in terms of associations between social class and factors that directly affect choice of university.

\section{References}

Adams, J.; Evenland, V. 2007. Marketing online degree programs: how do traditional residential programs compare?, Journal of Marketing for Higher Education 17(1): 67-90. http://dx.doi.org/10.1300/J050v17n01_06

Albadvi, A.; Chaharsooghi, S. K.; Esfahanipour, A. 2007. Decision making in stock trading: an application of PROMETHEE, European Journal of Operational Research 177(2): 673-683. http://dx.doi.org/10.1016/j.ejor.2005.11.022

Anctil, E. J. 2008. Selling higher education: marketing and advertising America's colleges and universities, ASHE Higher Education Report 34(2): 1-121.

Araz, C.; Mizrak, P.; Özkarahan, İ. 2007. An integrated multi-criteria decision-making methodology for outsourcing management, Computers \& Operations Research 34(12): 3738-3756. http://dx.doi.org/10.1016/j.cor.2006.01.014

Belton, V.; Stewart, T. J. 2002. Multiple criteria decision analysis: an integrated approach. London: Kluwer Academic Publishers. 372 p. http://dx.doi.org/10.1007/978-1-4615-1495-4

Bergerson, A. A. 2009. College choice as a comprehensive process, ASHE Higher Education Report 35: 21-46.

Bloom, D.; Canning, D.; Chan, K. 2005. Higher education and economic development in Africa. Harvard University. $84 \mathrm{p}$.

Brans, J. P.; Vincke, P. H. 1985. A preference ranking organization method, Management Science 31(6): 647-656. http://dx.doi.org/10.1287/mnsc.31.6.647

Brans, J. P.; Vincke, P. H.; Mareschall, B. 1986. How to select and how to rank projects: the PROMETHEE method, European Journal of Operational Research 14(2): 228-238. http://dx.doi.org/10.1016/0377-2217(86)90044-5

Brans, J. P.; Mareschall, B. 1994. The PROMCALC\&GAIA decision support system for multi-criteria decision aid, Decision Support Systems 12(4-5): 297-310. http://dx.doi.org/10.1016/0167-9236(94)90048-5

Briggs, S. 2006. An exploratory study of the factors influencing undergraduate student choice: the case of higher education in Scotland, Studies in Higher Education 31(6): 705-722.

http://dx.doi.org/10.1080/03075070601004333 
Briggs, S.; Wilson, A. 2007. Which university? A study of the influence of cost and information factors on Scottish undergraduate choice, Journal of Higher Education Policy and Management 29(1): 57-72. http://dx.doi.org/10.1080/13600800601175789

Broekemier, G. M.; Seshadri, S. 2000. Differences in college choice criteria between deciding students and their parents, Journal of Marketing for Higher Education 9(3): 1-13.

http://dx.doi.org/10.1300/J050v09n03_01

Cavalcante, C. A. V.; Ferreira, R. J. P.; De Almeida, A. T. 2010. A preventive maintenance decision model based on multi-criteria method PROMETHEE II integrated with Bayesian approach, IMA Journal of Management Mathematics 21(4): 333-348. http://dx.doi.org/10.1093/imaman/dpn017

Christie, H. 2007. Higher education and spatial (im)mobility: nontraditional students and living at home, Environment and Planning A 39(10): 2445-2463. http://dx.doi.org/10.1068/a38361

Conard, M. J.; Conard, M. A. 2000. An analysis of academic reputation as perceived by consumers of higher education, Journal of Marketing for Higher Education 9(4): 69-79.

http://dx.doi.org/10.1300/J050v09n04_05

Cremonini, L.; Westerheijden, D.; Enders, J. 2008. Disseminating the right information to the right audience: cultural determinants in the use (and misuse) of rankings, Higher Education 55(3): 373-385. http://dx.doi.org/10.1007/s10734-007-9062-8

Dağdeviren, M.; Eraslan, E. 2008. Priority determination in strategic energy policies in Turkey using analytic network process (ANP) with group decision making, International Journal of Energy Research 32(11): 1047-1057. http://dx.doi.org/10.1002/er.1418

Dağdeviren, M.; Yüksel, İ.; Kurt, M. 2008. A fuzzy analytic network process (ANP) model to identify faulty behaviors risk (FBR) in work systems, Safety Sciences 34: 96-107.

Edwards, D.; Coates, H.; Friedman, T. 2012. A survey of international practice in university admissions testing, Journal of Higher Education Management and Policy 24(1): 1-18.

http://dx.doi.org/10.1787/hemp-24-5k9bdck3bkr8

Fouladgar, M. M.; Yazdani-Chamzini, A.; Zavadskas, E. K.; Haji Moini, S. H. 2012. A new hybrid model for evaluating the working strategies: case study of construction company, Technological and Economic Development of Economy 18(1): 164-188. http://dx.doi.org/10.3846/20294913.2012.667270

Gordona, J.; Berhow, S. 2009. University websites and dialogic features for building relationships with potential students, Public Relations Review 35(2): 150-152.

http://dx.doi.org/10.1016/j.pubrev.2008.11.003

Goumas, M.; Lygerou, V. 2000. An extension of the PROMETHEE method for decision making in fuzzy environment: ranking of alternative energy exploitation projects, European Journal of Operational Research 123(3): 606-613. http://dx.doi.org/10.1016/S0377-2217(99)00093-4

Holdsworth, D. K.; Nind, D. 2006. Choice modeling New Zealand high school seniors' preferences for university education, Journal of Marketing for Higher Education 15(2): 81-102.

http://dx.doi.org/10.1300/J050v15n02_04

Kabak, M.; Burmaoğlu, S.; Kazançoğlu, Y. 2012. A fuzzy hybrid MCDM approach for professional selection, Expert Systems with Applications 39(3): 3516-3525. http://dx.doi.org/10.1016/j.eswa.2011.09.042

Karsak, E. E.; Sozer, S.; Alptekin, S. E. 2002. Production planning in quality function deployment using a combined analytical network process and goal programming approach, Computers and Industrial Engineering 44(1): 171-190. http://dx.doi.org/10.1016/S0360-8352(02)00191-2

Lee, J. W.; Kim, S. H. 2000. Using analytic network process and goal programming for interdependent information system project selection, Computers and Operations Research 27(4): 367-382. http://dx.doi.org/10.1016/S0305-0548(99)00057-X

Lei, S. A.; Chuang, N. K. 2010. Demographic factors influencing selection of an ideal graduate institution: a literature review with recommendations for implementation, College Student Journal 44(1): 84-96. 
Lin, W. T. 2008. Earthquake-induced landslide hazard monitoring and assessment using SOM and PROMETHEE techniques: a case study at the Chiufenershan area in central Taiwan, International Journal of Geographical Information Science 22(9): 995-1012. http://dx.doi.org/10.1080/13658810801914458

Lin, C. T.; Tsai, M. C. 2010. Location choice for direct foreign investment in new hospitals in China by using ANP and TOPSIS, Quality and Quantity 44(2):375-390. http://dx.doi.org/10.1007/s11135-008-9199-2

Meade, L. M.; Sarkis, J. 1999. Analyzing organizational project alternatives for agile manufacturing processes: an analytical network approach, International Journal of Production Research 37(2): 241-261. http://dx.doi.org/10.1080/002075499191751

Meade, L. M.; Presley, A. 2002. R\&D project selection using the analytic network process, IEEE Transactions on Engineering Management 49(1): 59-66. http://dx.doi.org/10.1109/17.985748

Menon, M. A.; Saiti, A.; Socratous, M. 2007. Rationality, information search and choice in higher education: evidence from Greece, Higher Education 54(5): 705-721. http://dx.doi.org/10.1007/s10734-006-9019-3

Mergias, I.; Moustakas, K.; Papadopoulos, A.; Loizidou, M. 2007. Multi-criteria decision aid approach for the selection of the best compromise management scheme for ELVs: the case of Cyprus, Journal of Hazardous Materials 147(3): 706-717. http://dx.doi.org/10.1016/j.jhazmat.2007.01.071

Mohanty, R. P.; Agarwal, R.; Choudhury, A. K.; Tiwari, M. K. 2005. A fuzzy ANP-based approach to R\&D project selection: a case study, International Journal of Production Research 43(24): 5199-5216. http://dx.doi.org/10.1080/00207540500219031

Nijkamp, P.; Rietveld, P.; Voogd, H. 1990. Multicriteria evaluation in physical planning. Amsterdam: Elsevier Science Publishers. 219 p.

Pampaloni, A. M. 2010. The influence of organizational image on college selection: what students seek in institutions of higher education, Journal of Marketing for Higher Education 20(1): 19-48. http://dx.doi.org/10.1080/08841241003788037

Paramasivam, V.; Senthil, V.; Ramasamy, N. R. 2011. Decision making in equipment selection: an integrated approach with digraph and matrix approach, AHP and ANP, International Journal of Advanced Manufacturing Technology 54(9-12): 1233-1244. http://dx.doi.org/10.1007/s00170-010-2997-4

Partovi, F. Y.; Corredoira, R. A. 2002. Quality function deployment for the good of soccer, European Journal of Operational Research 137(3): 642-656. http://dx.doi.org/10.1016/S0377-2217(01)00072-8

Poock, M. C.; Love, P. G. 2001. Factors influencing the program choice of doctoral students in higher education administration, NASPA Journal 38(2): 203-223.

Saaty, T. L.; Takizawa, M. 1986. Dependence and independence: from linear hierarchies to nonlinear networks, European Journal of Operational Research 26(2): 229-237. http://dx.doi.org/10.1016/0377-2217(86)90184-0

Saaty, T. L. 1996. Decision making with dependence and feedback: the analytic network process. Pittsburgh: RWS Publications.

Shyur, H.-J. 2006. COTS evaluation using modified TOPSIS and ANP, Applied Mathematics and Computation 177(1): 251-259. http://dx.doi.org/10.1016/j.amc.2005.11.006

Simões, C.; Soares, A. M. 2010. Applying to higher education: information sources and choice factors, Studies in Higher Education 35(4): 371-389. http://dx.doi.org/10.1080/03075070903096490

Sojkin, B.; Bartkowiak, P.; Skuza, A. 2011. Determinants of higher education choices and student satisfaction: the case of Poland, Higher Education 63(5): 565-581.

http://dx.doi.org/10.1007/s10734-011-9459-2

Soutar, G.; Turner, J. 2002. Students' preferences for university: a conjoint analysis, The International Journal of Educational Management 16(1): 40-45. http://dx.doi.org/10.1108/09513540210415523

Støren, L. A.; Arnesen, C. Å. 2007. Women's and men’s choice of higher education - what explains the persistent sex segregation in Norway?, Studies in Higher Education 32(2): 253-275.

http://dx.doi.org/10.1080/03075070701267293 
Taylor, J. S.; Brites, R.; Correia, F.; Farhangmehr, M.; Ferreira, B.; Machado, M. L. 2008. Strategic enrolment management: improving student satisfaction and success in Portugal, Higher Education Management and Policy 20(1): 129-145. http://dx.doi.org/10.1787/hemp-v20-art7-en

The CoHE - The Council of Higher Education. 2010. CoHE Announcements [online], [cited 15 March 2011]. Available from Internet: http://www.osym.gov.tr/dosya/1-56296/h/osysyerlestirmebulten2010.pdf

TUIK - Turkish Statistical Institute. 2008. [Online], [cited 12 January 2011]. Available from Internet: http://www.turkstat.gov.tr/Start.do;jsessionid=VhM7TTDWJGmGHvHxNxNF1gvbRf0cS8sn1ypFBJjyG7dDZF1Smd2j!572226980

Veloutsou, C.; Lewis, J. W.; Paton, R. A. 2004. University selection: information requirements and importance, The International Journal of Educational Management 18(3): 160-171. http://dx.doi.org/10.1108/09513540410527158

Vrontis, D.; Thrassou, A.; Melanthiou, Y. 2007. A contemporary higher education student choice model for developed countries, Journal of Business Research 60(9): 879-989. http://dx.doi.org/10.1016/j.jbusres.2007.01.023

Wang J. J.; Yang, D. L. 2007. Using a hybrid multi-criteria decision aid method for information systems outsourcing, Computers \& Operation Research 34(12): 3691-3700. http://dx.doi.org/10.1016/j.cor.2006.01.017

Warwick, J.; Mansfield, P. M. 2004. Perceived risk in college selection: differences in evaluative criteria used by students and parents, Journal of Marketing for Higher Education 13(1): 101-125. http://dx.doi.org/10.1300/J050v13n01_07

Wu, Y. W.; Sukoco, B. D.; Li, C. Y.; Chen, S. H. 2009. An integrated multi-objective decision-making process for supplier selection with bundling problem, Expert Systems with Applications 36(2): 2327-2337. http://dx.doi.org/10.1016/j.eswa.2007.12.022

Wu, W.; Kou, G.; Peng, Y.; Ergu, D. 2012. Improved AHP-group decision making for investment strategy selection, Technological and Economic Development of Economy 18(2): 299-316. http://dx.doi.org/10.3846/20294913.2012.680520

Yazgan, H. R.; Boran, S.; Göztepe, K. 2010. Selection of dispatching rules in FMS: ANP model based on BOCR with choquet integral, International Journal of Advanced Manufacturing Technology 49(5-8): 785-801. http://dx.doi.org/10.1007/s00170-009-2416-x

Yüksel, İ.; Dağdeviren, M. 2007. Using the analytic network process (ANP) in a SWOT analysis-a case study for a textile firm, Information Sciences 177(16): 3364-3382. http://dx.doi.org/10.1016/j.ins.2007.01.001

Mehmet KABAK received his Master's Degree (Defense Technologies) from Istanbul Technical University and $\mathrm{PhD}$ (Operations Research) from the University of Marmara, in 2001 and 2005 respectively. Currently, he is an Assoc. Professor affiliated to the Department of Industrial and System Engineering, Turkish Military Academy, Ankara, Turkey. His research areas include resource optimization, energy, strategic management, multi attribute decision making, fuzzy logic, etc.

Metin DAĞDEVIREN received his Doctoral Degree (Industrial Engineering) from Gazi University, Turkey, in 2005. Currently, he is an Assoc. Professor and the Vice Dean of the Faculty of Engineering. His research areas include work study, human resource management, multi attribute decision making, strategic management, fuzzy logic, etc. 